Arab World English Journal (AWEJ) $2^{\text {nd }}$ Special Issue on Covid 19 Challenges January 2022 DOI: https://dx.doi.org/10.24093/awej/covid2.4

\title{
Sustainability of Foreign Language Education at a Slovak University during COVID-19 Global Pandemic
}

\author{
Olena Hundarenko \\ Department of English Language and Literature \\ Faculty of Humanities, University of Zilina, Slovakia \\ Corresponding Author: olena.hundarenko@fhv.uniza.sk
}

\author{
Eva Leláková \\ Department of English Language and Literature, Faculty of Humanities \\ University of Zilina, Slovakia \\ Beatrix Bačová \\ Department of Structural Mechanics and Applied Mathematics \\ Faculty of Civil Engineering, University of Zilina, Slovakia
}

Received: 11/12/2021

Accepted: $12 / 1 / 2021$

Published:1/24/2022

\section{Abstract}

The current paper scrutinizes the students' voice on the educational COVID-19 based changes that occurred at the Department of English Language and Literature, Faculty of Humanities, University of Žilina, Slovakia. The respondents' study program is Teaching English Language and Literature. The significance of the study lies in the urgent need of today's educators to detect students' views on new modes of studying applicable these days to find beneficial solutions for the provision of high-quality education services. The focal point has been placed on the students' voice, i.e., on the students' comparative approach towards current online and traditional classroom mode of studying/learning. The research has been supported by a questionnaire with 11 EFL-related statements to test the hypotheses of this study. Hence, the objectives of the research have been to compare the quality of education performed through the online and offline classroom frameworks, evaluate the effectiveness of the students' language skills development, and track students' level of satisfaction with the running online model of studying all this viewed and uttered by students themselves. The current research employs "mixed methods" that imply the integration of quantitative and qualitative data within a single inquiry. Overall, $61.6 \%$ of the surveyed students expressed their satisfaction with the blended learning system and their readiness to apply it in further teaching practice. This research is not exhaustive and might broaden into a comparative study of the students' language-related feedback of the online/offline education among other European and non-European English language departments, building a substantial basis for policy decisions.

Keywords: Covid-19 impact, foreign language education, blended learning system, pros and cons of online EFL mode, Slovak students' voice

Cite as: Hundarenko, O., Leláková, E., \& Bačová, B. (2022). Sustainability of Foreign Language Education at a Slovak University during COVID-19 Global Pandemic. Arab World English Journal (AWEJ) $2^{\text {nd }}$ Special Issue on Covid 19 Challenges (2) 48 -63.

DOI: https://dx.doi.org/10.24093/awej/covid2.4 


\section{Introduction}

The beginning of the year 2020 took an unprecedented meander and undermined all the expectations of academicians worldwide. A COVID-19 virus outbreak originated in Wuhan, China, and its quick and massive spread impacted an education industry, which had to reconsider all the previously set up strategies and methods and make modifications in the teacher-training area. Many academic establishments ranging from primary schools to universities have terminated the offline/presence-based studying process and shifted online. It was a real challenge both for students and educators worldwide. Online mode, to a big expectation, had to flatten the curve and normalize the situation in the nearest future. However, no one can confirm today that the closure of educational establishments was an effective measure then (Viner et al., 2020).

As the number of international publications on COVID-19 impact on education proves (Allen, Rowan, \& Singh, 2020; Burgess \& Sievertsen, 2020; Chandasiri, 2020; Dutta, 2020; Ferdig, Baumgartner, Hartshorne, Kaplan-Rakowski, \& Mouza, 2020; Hodges, Moore, Lockee, Trust, \& Bond, 2020; Karchmer-Klein \& Pytash, 2020; Mariononi, Land, \& Jensen 2020; Odriozola-González, 2020; Sahu, 2020; Soland, Kuhfeld, Tarasawa, Johnson, Ruzek, \& Liu, 2020; Stukalo \& Simakhova, 2020, and many others), a lot of educational institutions were not ready for changing a long-practiced mode of classroom-based teaching as well as finding new effective (online) methods while the situation gets stabilized. Every school in the world could issue its own story based on new experiences and observations, advantages and disadvantages of the selected approaches, and fulfilled or failed expectations connected with the platforms used, methods implemented, and curricular organized.

Based on our own teaching experience, we were aware of all the milestones, which together with our courageous students, we all had to encounter and manage. To get a more accurate image of the COVID-19 based changes in the traditional university classroom environment, we appealed to our English department students with the request to respond to a specially prepared survey honestly. Doing so, we aimed at receiving their frank feedback on online teaching/studying process with its weaknesses and strengths. The students were encouraged to express their viewpoints on the future perspectives of the offline/vs. online studying modes and, more importantly, their suggestions and recommendations. We have been learning together during this uneasy and challenging period of academic and non-academic life with the common goal to make education an effective and motivating tool despite any hurdles the $21^{\text {st }}$ - century might offer.

This inquiry has been executed to determine how the online mode of studying affected academic efficiency within the Slovak EFL university curriculum. It was aimed to specifically analyze the changes occurred in the educational process of the students of the teacher training study program Teaching English Language and Literature offered by the Department of English Language and Literature, Faculty of Humanities, University of Žilina, Slovakia as well as to analyze their future teaching perspectives and expectations.

The following section investigates the factors that have both inspired and hindered the learning of languages during the first months of the pandemic situation in Slovakia. 


\section{Literature Review}

In reference to Slovak schools and universities, their system, along with the systems of most other Central European countries, has long been characterized by a traditional classroom learning conducted in a synchronous environment. Online platform or blended teaching/learning approach has not been frequently applied as there has been a persisting fear of insufficiency of technical devices, low technological proficiency of teachers and students (Metruk, 2020), weak motivation and flexibility, and time management problems. Therefore, after the pandemic began, significant reconsiderations and modifications in most syllabi and curricular of all the educational institutions had to be done. In the beginning, there were disagreements and disputes based on the choice of the most suitable platform (e.g., Zoom, Microsoft Teams, Moodle, Skype, Google Meet, etc.), as each of them had its own strong and weak points. At that time, students could choose the one they liked the best, but various platforms used daily for different students and subjects caused chaos and incoherency in the educational process. The situation seemed even more strained when thinking about the upcoming exams and their format. By joint effort, the problem got ameliorated and a new educational era (a COVID-19 dependent one) became a daily reality with most adjustments and adaptations processed and executed.

When we started to teach online, we were aware that our students were taught linguistically so far. In a traditional classroom setting, they were used to listening to us and writing the notes down and asking us directly in case they had any subject-related or even subject-unrelated issues. Therefore, when a temporary online COVID-19 era came, we needed to assure them that in a new learning environment, we, English teachers, would still be present there to give them all the previous support (social and emotional included), which they were so scared to lose. As there was not enough time and essential financial sources for a radical change of the educational process, we decided to improve the existing teaching methods by the elements taken from the up-to-date and scientifically based theories on online education.

Hence, we got inspired by Anderson's model of online learning (2011), Picciano's Blending with Pedagogical Purpose Model (2009), Siemens' principles of connectivism (2004), Harasim's theory of online collaborative learning (2012), and the Quality framework designed by the Online Learning Consortium (online, 2021). To be more precise, firstly, we were cautious about providing the students left in an online space with the education of the comparable high quality to the one they used to be given in their traditional classroom. Secondly, we were aware that our students needed a lot of visualization stimuli that would enhance their learning process and keep them engaged; therefore, we started to use and develop even more digital images, texts, audios, and videos (e.g., TED talks, ESL Brains, etc.).

The role of a lecturer and supervisor had to be suddenly enriched by a function of a new e-content developer (Adebisi \& Oyeleke, 2018; Williams, 2003), and our way of thinking of professional training and sharing expertise (Crane, 2020) was shifted too. As English language experts, we were expected to enhance our learners' productive and receptive language skills by using cognitive and metacognitive strategies (Xiao \& Hurd, 2007; Dorand, 2020; Lacková, 2021). Moreover, we also had to learn how to deliver our demanding students - prospective English language teachers - clear and unambiguous instructions, even though their delivery system (Ushida, 2005), design (Alberth, 2011), and learning place considerably changed. Thirdly, we tried to maintain as much online connection with students (and among them) as 
possible to provide enough space for the expression of their viewpoints, to use higher-order skills (Çakici, 2016), to think critically (Grasse, 2020; Coyle, 2019; Kosturková, 2011), to see connections between the presented ideas and be able to facilitate and encourage them (Hrotková, 2010). We aimed to support them so that they start to be proactive and motivated to become gradually independent and autonomous learners (Stukalo \& Simakhova, 2020; Our Quality Framework, 2021) and one day creative teachers with all these skills utilized. All these necessary changes were very challenging for us, teachers, too, as we also needed motivation, courage, and practice to use them with confidence. After a year of innovative teaching, lecturing, discussions, consultations, testing and examinations, there came the time for evaluating their sustainability and success through the anonymous survey answered by our students.

\section{Methods}

The present research employs "mixed methods" integrating quantitative and qualitative data within a single inquiry. The benefits of this methodology are explicable due to synergetic exertion of both types of data.

Before carrying out the study, we had examined several classifications of mixed methods and designs applicable in educational inquiries (Tashakkori \& Teddlie, 1998; Creswell, 1999; Creswell, Clark, Gutmann, \& Hanson, 2003; Creswell \& Clark, 2006; Greene, 2007; Fabian, 2020). Our ultimate task was to decide among the four major types of mixed methods designs, i.e., the Triangulation Design, the Embedded Design, the Explanatory Design, and the Exploratory Design.

Finally, due to its premises, we decided to implement into our research the framework of the Explanatory design (also known as the Explanatory Sequential Design). It represents a twophase mixed method design, where qualitative data help to explain or build upon initial quantitative results (Creswell et al., 2003). This design is a great asset to the study in which a researcher needs to explain some essential or surprising results (Morse, 1991). Its first phase the collection and interpretation of quantitative data - is immediately followed by the second phase, the qualitative one, offering an in-depth qualitative study to elucidate why such results appeared. The Explanatory Design envisages two variants: the follow-up explanation model and the participant selection model. In our research, we tend to incorporate the follow-up explanation model as it focuses on detailed scrutinizing of the results obtained. The follow-up explanation model is relevant when a researcher needs qualitative data to explain or expand on quantitative results (Creswell et al., 2003). Hence, the researcher can choose which quantitative findings need additional clarification. For us, it seemed a very effective implement since our primary goal was to get statistical figures to answer the research questions and simultaneously to get a deeper insight into the nature of some replies. Thus, while collecting some quantitative survey data (closed-ended), we used open-ended questions to learn about the reasons and background of a definite choice made by our respondents. As Gillham (2000) wittily notices, "open questions can lead to a greater level of discovery" (p. 5). We do believe that by integrating open-ended data we can achieve more precise and trustworthy results in the end.

\section{Research objectives}

The focal point of the inquiry has been placed on the students' voice, i.e., on the students' comparative approach towards current online and traditional classroom mode of 
studying/learning. For this purpose, the survey has been aimed at only those students who major in English, who have prior experience of EFL classes at the Department of English Language and Literature, Faculty of Humanities, University of Žilina, Slovakia. The research has been effectuated by addressing the students with 11 EFL-related questions which were closely interrelated with our three introductory online teaching aims. The questions were formulated in a way to fall into one of the subcategories:

1. Sustainability of a high quality of education during the online teaching/learning process.

2. Students' language skills development in the online environment.

3. Students' satisfaction with the online model of education.

The outcome of the three sets of questions, making up a survey, was the construction of the three major hypotheses as the focal point of our research, namely:

Hypothesis 1 (H1): When teaching online, the quality of English language teaching and learning has remained the same in comparison with the quality of classroom education.

Hypothesis 2 (H2): From the viewpoint of students, their language skills have worsened during the online learning/teaching period. education.

Hypothesis 3 (H3): Most of the students have accepted and appreciated the online way of

\section{Participants}

In order to receive clear and accurate research results, we incorporated probability sampling: it embraced the Slovak university students being enrolled in the academic year 2020/2021 in both BC and MA English language and literature teacher training study programs at the Faculty of Humanities in Žilina. We excluded the first-year BC students from the research, as our goal was to conduct a comparative analysis of advantages and disadvantages of the online and offline studying processes among those students who had prior awareness of either of them or were able to explain their viewpoints related to university-based curriculum. The niche of our research was limited to future teachers (currently BC and MA students), since their replies were supposed to be somewhat topical and sufficient for finding practical solutions for online education needs provision. The number of interviewees reached 73 in total, with 75,5\% females, and $20,5 \%$ males. As a result, $97 \%$ of them were of a Slovak citizenship, while the other $3 \%$ represented Ukrainian and Russian students.

\section{Data Collection}

Data collection was exclusively conducted between 15th February 2021 - 1st March 2021. The online questionnaire created with Google Drive Tool was thoroughly inspected and sent out to the respondents' school email addresses. They were instructed to answer the questions based on their experience in online learning/studying process merely at the Department of English and Literature. We were interested in the challenges and new skills they got while having their major English language-based subjects: Morphology, Syntax, Lexicology, Phonetics, Academic Writing, Literature, RKK, and others. Students were also informed that all the responses would be held and treated in strict confidence and used only for research purposes. For this reason, no names were required. The approximate time they needed for filling in the questionnaire was 15-20 minutes. 


\section{Research procedure}

Formal Characteristics

The online survey employed the following four sections:

Section 1: general information which required personal data (age, gender, nationality, language/s, years of study, degree, etc.).

Section 2: technical issues of online learning - honest replies to "technically-related questions". The goal was to understand what worked well and what failed during the online process of studying.

Section 3: the main part referring to language issues of online learning. This section included both closed-ended and open-ended questions on the significant language-based research inquiries.

Section 4: feedback, recommendations, and suggestions of the respondents.

The focus of this research paper is given predominantly to sections three and four of the survey. Section one served just for introductory purposes. We intentionally decided to omit further expansion and interpretation of the section two (survey data devoted to the technical issues). Hence, only occasional demonstrative examples will be highlighted here, since it was extensively elaborated in many relevant studies worldwide (see introduction of this paper), and many aspects seem interlacing. This part of the inquiry is left out for our internal purposes: to improve and vary online tools and platforms, and to advance teaching possibilities within the recommended media.

\section{Findings}

The priority of the research was given to language-related questions for the purpose of drawing out all relevant data by employing both quantitative and qualitative research methods.

The first subcategory of questions (Q1-Q3) referred to the sustainability of a high quality of education.

Question 1: Is teaching English subjects much different from a conventional classroom one?

Is teaching English subjects much different from a conventional classroom one?
73 responses

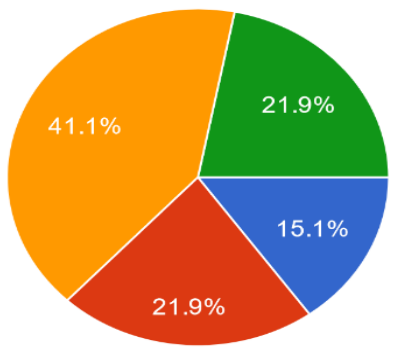

Yes, a lot

Yes, a bit

Not at all

Hard to say

Figure 1. Differences between online and presence teaching evaluated by the students

Overall, only $37 \%$ of the students discern the differences between the online and offline education. They elucidate the differences especially in: 
a. personal and online contact between a teacher and students (in 15 cases):

"Eye contact is really important to me whether it is with my classmates or teachers - it helps me communicate." "The whole class atmosphere is simply better and more professional when we are face to face in a real classroom."

b. problems with concentration and motivation in the studying process (in five cases):

"I can't concentrate even though I try." "There is much more distraction at your home, therefore learning is quite harder for me."

c. technical issues in educational process (in six cases):

"Also, the Internet connection is not always the best and it ruins the whole learning experience."

"There can also be a communication problem that can be caused by the Internet or Wi-Fi connection."

d. communication issues (in four cases):

"Many classmates are shy to answer, thus making the lecture awkward..." "It is hard to interrupt the teacher to ask something." "I personally hate the silence when the teacher asks for feedback."

e. learning/teaching techniques (in three cases):

"I would screenshot the screen instead of writing down notes with my hand so studying the lectures afterward was harder before." "Lack of group practice, pair work and speaking activities".

The group of 30 students $(41.1 \%)$ consider the online and classroom teaching very similar, and for 16 students (21.9\%), it is hard to decide - this can also refer to the inability to see the difference between two approaches. Hence, we might deduce that $63 \%$ of the respondents (=students) cannot spot a significant distinction between a classroom and online form of teaching.

"There is no difference in difficulty caused by online platform learning for me. It is only more convenient."

Question 2: Did you have more problems with concentration during online English language learning in comparison to a classroom form of learning?

As expected, students confirmed that they had problems with concentration during their classes. Totally $60,4 \%$ of them could not concentrate as much as they wished to. They elucidated it by the fact that their active/passive presence was difficult to detect, and they were also distracted by the home environment. On the other hand, $38.4 \%$ of students concentrated better online than in the classroom.

"Sending and working with given materials was easier, it was easier to concentrate on learning." "The most important benefit for me is that I can concentrate better at home, because I am alone in my room." 


\section{Question 3: Will you evaluate your online English-based university studying process as an effective one?}

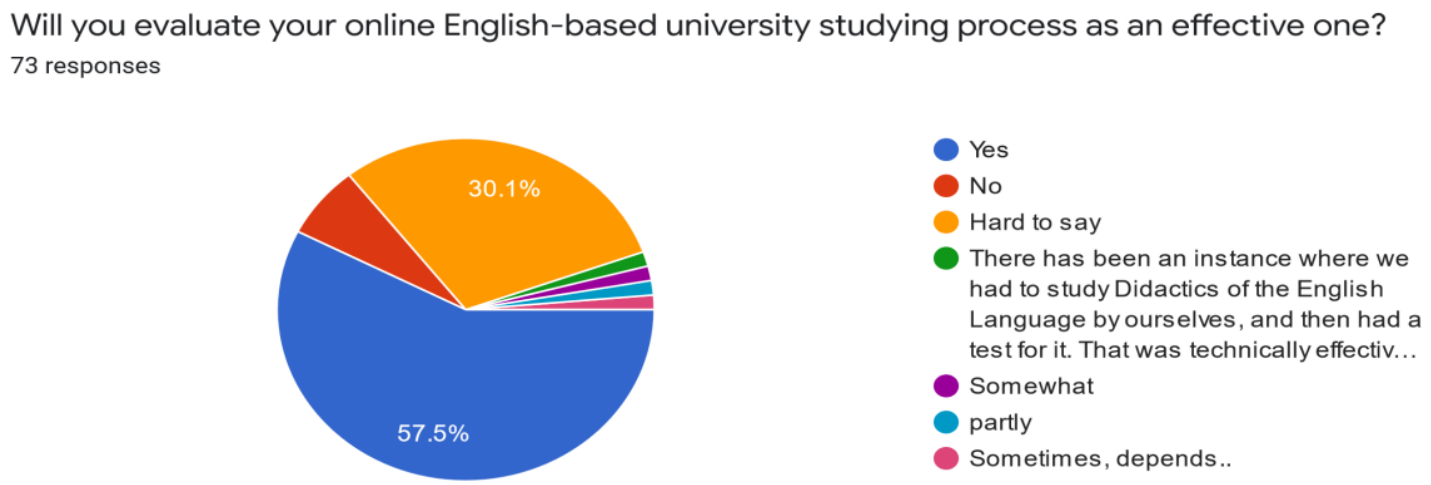

Figure 2. Students' evaluation of the effectiveness of the online studying process

Overall, .5\% of the addressed students assessed an online studying process as an effective one. Just $6.8 \%$ asserted that the process was ineffective. The rest of them $(35.7 \%)$ were indecisive in their replies. Just one of the respondents gave a particular example of ineffectiveness: "There has been an instance where we had to study Didactics of the English Language by ourselves, and then had a test for it. That was technically effective, but I hardly learned anything." The other respondent gave a piece of advice: "I would add more hours. We are at home so many of us have a lot of free time. It would be much more effective for me." On the other hand, we received the replies: "Online learning/teaching did not change the way how our teachers communicate and behave towards us, students. Our teachers helped us as much as they could."

After collecting, analyzing, and summarizing all the students' responses, we can claim that Hypothesis 1 (H1: When teaching online, the quality of English language teaching and learning has remained the same in comparison with the quality of classroom education.) has been confirmed. Even though $31.5 \%$ of all the students had quite a big issue with the concentration, $63 \%$ of them could not see a serious distinction between a classroom and online form of teaching. Only $6.8 \%$ of them asserted that the process was not productive.

The second subcategory, referring to language skills development, included five questions (Q4 - Q8):

Question 4: Which aspect/s of online English language learning is the most challenging/the least challenging one for you?

Based on the respondents' replies, we can summarize that speaking (43.8\%) and grammar activities (31.5\%) are the most challenging aspects for the students in an online educational process. On the other hand, listening activities (45.2\%) and reading activities (47.9\%) are less difficult. Writing and vocabulary activities are ranked neither the most nor the least challenging ones. 
"Grammar (syntax) - it just needs time to understand it properly." "Speaking - speaking time in class is not enough when happening online, not enough pair and group work."

Question 5: Did your communication skills improve/worsen during an online educational process?
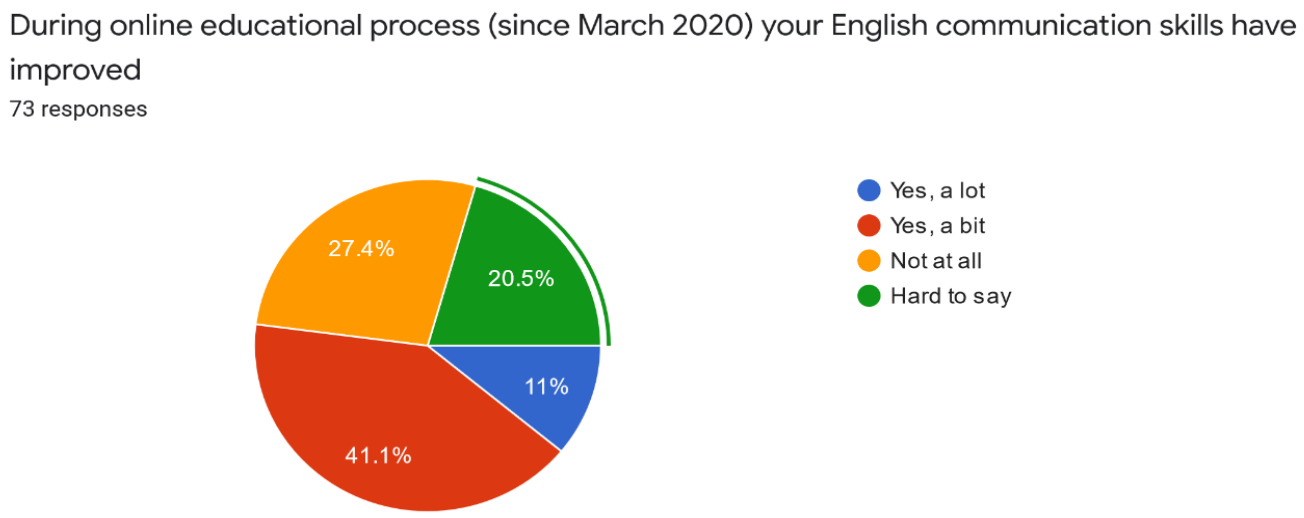

$$
\begin{aligned}
& \text { Yes, a lot } \\
& \text { Yes, a bit } \\
& \text { Not at all } \\
& \text { Hard to say }
\end{aligned}
$$

Figure 3. English language communication skills improvement

Concerning the English language communication skills of the students, 52.1\% think that they have improved since March 2020. Only 27.4\% of them claim that the improvement has not been considerable and sufficient. $20.5 \%$ of respondents are not definite in their opinion.

"Language anxiety disappeared. We are much more confident when speaking in front of our laptops." "I think we were speaking more."

\section{process?}

Question 6: Did your listening skills improve/worsen during online educational

Overall, 51 students $(69.9 \%)$ responded that their listening skills had improved during the period of online education. They remarked that they watched videos and/or had listening activities/tasks during their online English lessons, and the activities were natural, refreshing and motivating for them. Eight students (11.2\%) were indecisive in their answers, and this fact can also lead us to the assumption that their listening skills have not worsened. Fourteen Students $(19.2 \%)$ claimed that their listening skills had further exacerbated during online education.

"There is no "background noise" (everyone is muted unless the teacher permits to speak). In an actual class, for example during RKK listening exam, I might have difficulty hearing the audio track if I sit too far from it. Online, this obstacle has been erased."

Question 7: Did your writing skills improve/worsen during online educational process?

On the whole, $52.1 \%$ (compared to $27.4 \%$ ) of the students think that their writing skills have improved. Since March 2020, the written assignments have been continuously given to them by their English language instructors. They included project works, seminar works, writing essays, and subject-based syntax and stylistic tasks. However, they would still like to get more of them.

"I would recommend focusing on enrolling students in long-term projects that will take time over the entire semester." 


\section{process? \\ Question 8: Did your English grammar improve/worsen during online educational}

Once again, more than half of the respondents (57.5\% - opposing to $24.7 \%)$ think that their grammatical competence has improved; $17.8 \%$ of them are not quite sure if their grammar knowledge has refined or not. The students consider grammar subjects to be challenging and time-consuming ones, because they require a lot of concentration, sometimes also learning by heart. Hence, the students suggest more hours of grammar be included in the online curriculum.

"With grammar subjects in general you need to pay $300 \%$ attention." Syntax is harder to explain and students don't have enough time to ask questions." "Morphology itself is hard enough, it being online just made it harder. And it can't be blamed on anyone, it is what it is and we have to deal with it and adapt."

After analyzing Q4-Q8, we can assume that Hypothesis 2 (H2: From the viewpoint of the students, their language skills have worsened during the online learning/teaching period.) was rejected as more than half of the respondents in their critical self-assessment replies believe their language skills have improved.

The third subcategory, referring to the students' acceptance of online educational model, included three questions (Q9 - Q11):

Question 9: Which English language subject/s from the curriculum do you consider the most convenient for online teaching/learning process?

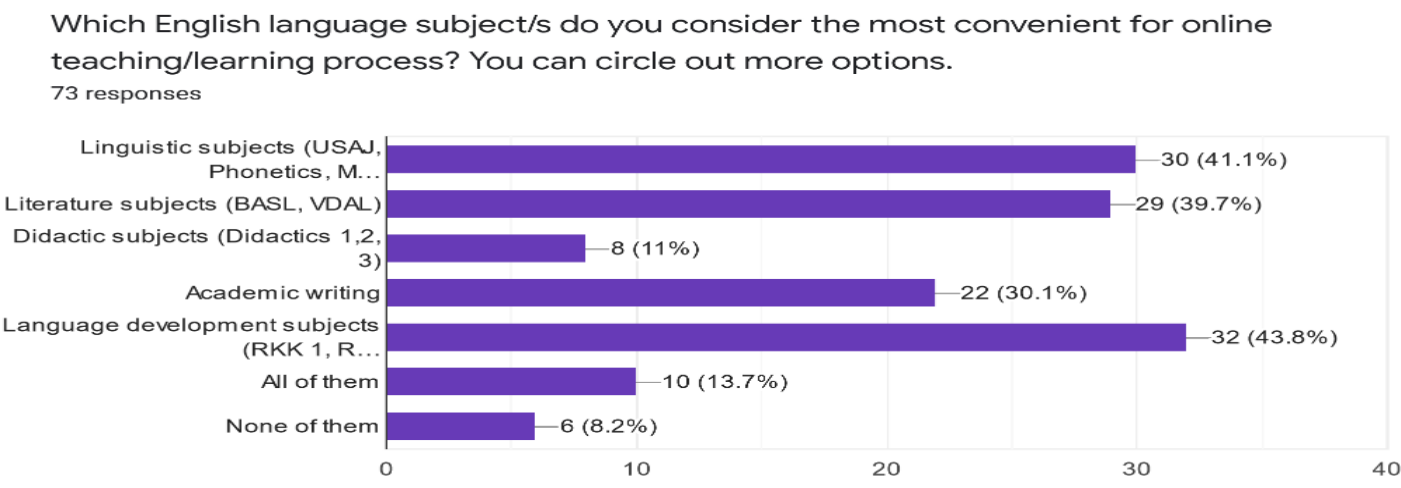

Figure 4. Students' view on English language convenience for online studying

Resulting from the research data, we can conclude that the students diverge substantially in their opinions. Although 30 out of 73 interviewed students think that linguistic subjects are convenient for online processes, 43 students either disagree or do not have a clear view on it, e.g.:

"Well morphology and grammar subjects in general you need to pay $300 \%$ attention, but you are at home... you have mess on a desk... cat is chewing some plastics in background... so it's not so easy always."

When observing their viewpoints on literature subjects (BASL - British and American Studies and Literature, VDAL - Landmarks of Anglophone Literature), 39.7\% of them prefer 
studying them online. The rest of them either favor their classroom activities or are indecisive in this issue.

"I think BASAL - it's just about theory so it's completely fine to have this subject online." "I just think that in Literature subjects it is more important to discuss your ideas and this is more comfortable to do it in a class."

Language development subjects are evaluated by students as the most convenient ones for online education ( $43.8 \%$ of students):

"The RKK seminars felt smooth for me, even though we did listen to the recordings from the $\mathrm{CD}$ through a speaker playing through our laptop speakers."

$13.7 \%$ of the students (=10 respondents) think that all the English language subjects are suitable for the online educational process:

"I liked all the subjects that we covered, and it does not matter if it is online or a regular lesson in the class. I consider them all as convenient as we can learn a lot from each of them."

Question 10: As prospective teachers, based on your personal experience, can you imagine teaching English-based subjects effectively online in the future?

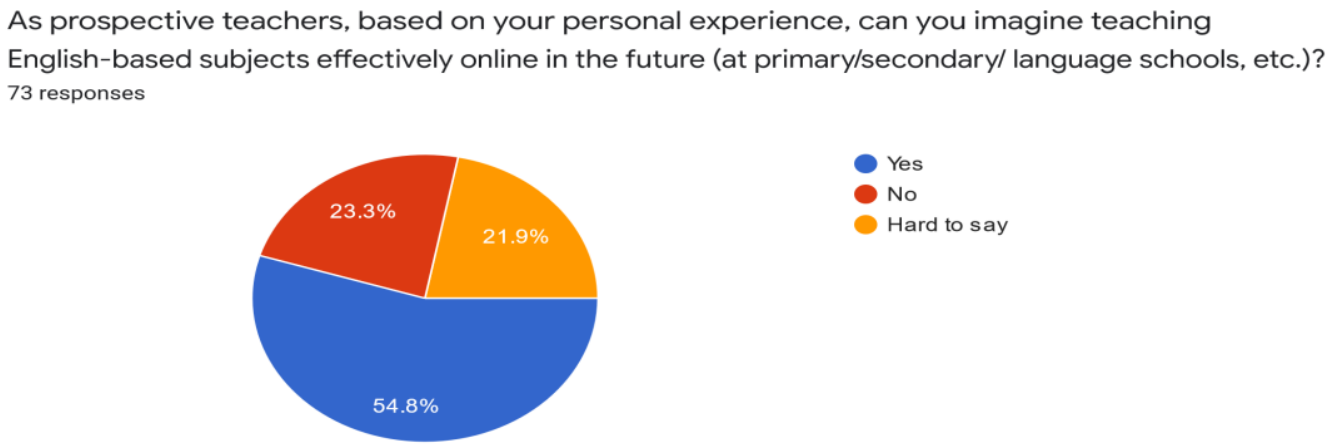

Figure 5. Students' willingness to teach online in the future

Only $17(23.3 \%)$ of 73 students cannot imagine their teaching online in the future. For 16 students, i.e., $21.9 \%$, it is hard to decide now whether they are going to try this form hereafter. However, 40 students (54.8\%) will take this option into consideration when teaching.

"Every English language subject can be adjusted to the online teaching/learning process and use the online tools accordingly to the subject."

Question 11: Would you choose a combination of online and traditional classroom teaching/learning in the future?

From the research results, it is evident that only 12 out of 73 students $(16,4 \%)$ object to the combined form of teaching in the future. 61 students (84\%) are almost ready to integrate online elements in their daily teaching. They just think that they are not still prepared to teach everything online and will need more practice in the future.

"I think it will depend on the teacher's method of teaching." "It depends on teachers and their skills to work with class online in the same way as in conventional classroom". 
The answers of the students to the Q9-Q11 have confirmed Hypothesis 3 (H3: Most of the students have accepted and appreciated the online way of education.). Appreciative and positive comments of the respondents prevailed considerably over the judgmental ones. These findings lead us to the assumption that the teaching approaches and methods we selected at the beginning of the online educational process in March 2020 and which we applied during the whole time of its lasting were rather helpful and appropriate. However, it should be emphasized that they were constantly being improved as they went along. And based on the students' suggestions and recommendations given in the survey, we can come up with even more perfections in the next academic years.

To sum it up, among the chief appreciable strengths of the online mode of learning of the English language-related subjects, we can rank better concentration, a variety of interactive activities, easier organization of study materials, and more speaking activities. Meanwhile, more inquisitive viewpoints elucidate more inclusive space for students with disabilities, language anxiety disappearance, and more confidence when speaking in front of the laptops. Students refer to online education as a life experience, as something they will need in future. They highly appreciate the guidance and support of English language teachers: "Online learning/teaching did not change the way how our teachers communicate and behave towards us, students. Our teachers helped us as much as they could."

Furthermore, the students in many cases express their mere gratitude for the opportunity to study during this exceptional period, "...during a pandemic we can just study and I'm glad for that, because there is at least some compensation of normal studying, so we still have that chance to at least study online. Overall, I think the whole learning is fine, except for the lack of socialization." These opinions motivate and inspire us for a continuous search of effective platforms, tools, and methods that might make an online mode of learning quality relevant to the needs of the $21^{\text {st }}$ - century learner.

\section{Discussion}

The conducted survey has reflected the students' voices on the advantages and disadvantages of the online language-based educational process on the background of the instance of the English language department focused on training future teachers at the selected university in Slovakia. A positive sign is that the students, who were involved in the survey, addressed the existing circumstances with a positive manner and even highlighted a lot of benefits they could behold. Moreover, they satisfactorily assessed and expressed their readiness to accept a blended learning system as their prospective teaching tool $-61.6 \%$ of the surveyed students after one year of "emergency online education" demonstrated their readiness to further study in a mixed online and traditional classroom setting. Based on the research results, we can summarize that our students have appreciated our endeavor to provide sustainable education.

Getting inspiration from both national and international colleagues' practical experience full of either successes or failures, challenges and achievements during COVID-19 era, namely: Australian (Allen, Rowan, \& Singh, 2020), UK (Burgess \& Sievertsen, 2020), Spanish (Odriozola-González, 2020); Bangladesh (Dutta, 2020), the USA (Soland et al., 2020), Ukrainian (Stukalo \& Simakhova, 2020), as well as getting acquainted with selected case-studies all around the world (Mariononi, Land, \& Jensen 2020), we shaped our own methodology and 
adjusted it to Slovak EFL students in order to sustain the quality of language education irrespective of outside hurdles.

As a result, many of the respondents proved by claiming that the previous high quality of education remained unchanged. They also expressed their satisfaction with the development of their productive and receptive language skills; they accepted a new online delivery system, design and learning place without serious objections and confirmed to have had a sufficient space for the expression of their viewpoints and for seeing connections between the presented ideas. The online learning/teaching period certainly has not demotivated them to become creative teachers with all the necessary skills one day in the future.

Hence, we believe that the exposed inquires will assist our colleagues in other educational institutions to apprehend the outspoken challenges of the Slovak university students who have a strong ambition to become primary and secondary school teachers. The research results should motivate both participants of the educational process to collaborate and find beneficial solutions for the provision of high-quality education service in the times of online education. Today's educators appear to be in the epicenter of global online teaching epoch which entails new challenges and opportunities for professional collaboration worldwide.

For this reason, our conviction is that the more educators globally express their concerns and share their apprehension of the emergent situation, the quicker and more effectively we will all step into a new mode of daily online teaching responsibilities, which might be our everyday reality for a few upcoming semesters (fully or partially). One obvious point that the COVID-19 pandemic has elucidated for all of us is the need for increased international and global perspectives to interpret the various impacts of COVID-19 in the short, medium, and long term.

\section{Conclusion}

In conclusion, we believe that the overall analysis and comprehension of the stated problem will help generate our combined effort and provide constructive recommendations on provision of high-quality education service even in the times of "emergency online education". To confront medium- and long-term scenarios, we should observe and apprehend what is happening at present. A blended learning system is becoming more applicable. Therefore, a novel education system should be seen not as a hurdle but rather a challenge for new opportunities, new realities, and new paths for professional collaboration worldwide.

The possible next step of the research can be a comparison of the students' languagerelated feedback on the online/offline education mode among other departments of the Faculty of Humanities at the University of Žilina, Slovakia. By spotting the milestones locally, we plan to integrate this knowledge into bigger research hereafter. It will, therefore, provide a reasonable basis for further decisions primarily on the home-university level, and it can also become an asset to the national and all-European report as a substantial basis for policy decisions. What is more, it can be forecasted that there will be a tremendous value in the research published after the pandemic that looks back to find out what worked, what did not work, and what could be learned to improve current and future practice. 
Arab World English Journal (AWEJ) 2nd Special Issue on Covid 19 Challenges January 2022

Sustainability of Foreign Language Education at a Slovak University

Hundarenko, Leláková \& Bačová

\title{
Acknowledgment
}

This paper has been published with the support of the Cultural and Educational Grant Agency of Slovak Ministry of Education, project:019ŽU- 4/2020.

\begin{abstract}
About the authors:
Dr. Olena Hundarenko works as a senior lecturer at the Department of English Language and Literature, Faculty of Humanities, the University of Žilina, Slovakia. The focal point of her research is academic writing and writing for EFL/ESL students, public speaking, discourse analysis and various topics within stylistics and morphology linguistic disciplines. https://orcid.org/0000-0002-4642-7160
\end{abstract}

Dr. Eva Leláková works as a senior lecturer at the Department of English Language and Literature, Faculty of Humanities, the University of Žilina, Slovakia. In her research she focuses on the comparative analyses of specific lexico-semantic fields, syntactic structures of literary texts, corpus linguistics and application of the results of the matrix theory in the teaching theory and practice. https://orcid.org/0000-0002-5294-2505

Beatrix Bačová works as a senior lecturer at the Department of Structural Mechanics and Applied Mathematics at the Faculty of Civil Engineering, the University of Žilina, Slovakia. In her research she focuses on implementation of ICT in the teaching of mathematics using a mathematical programme MATLAB and on the statistical processing of the research results of various scientific fields. https://orcid.org/0000-0002-3486-2026

\section{References}

Adebisi, T.A., \& Oyeleke, O. (2018). Promoting Effective Teaching and Learning in Online Environment: A Blend of Pedagogical and Andragogical Models. Bulgarian Journal of Science and Education Policy, 12(1), 153-172.

Alberth, A. (2011). Critical Success Factors in Online Language Learning. TEFLIN Journal 22(1), 16-30. DOI: 10.15639/teflinjournal.v22i1/16-33

Anderson, T. (2011). The Theory and Practice of Online Learning. Edmonton: AU Press.

Allen, J., Rowan, L., \& Singh, P., (2020). Teaching and Teacher Education in the Time of COVID-19. Asia-Pacific Journal of Teacher Education, 48(3), 233-236.

DOI: https://doi.org/10.1080/1359866X.2020.1752051

Burgess, S., \& Sievertsen, H., (2020). Schools, Skills, and Learning: The Impact of COVID-19 on Education. VoxEU. Retrieved from https://voxeu.org/article/impact-covid-19education

Çakici, D., (2016). The Use of ICT in Teaching English as a Foreign Language. Participatory Educational Research (PER), IV, 73-77.

Coyle, D. (2019). Designing Strategic Classrooms: Self-Assessment in Enabling Self-Regulated Learning. In A. U. Chamot, \& V. Harris (Eds.), Learning Strategy Instruction in the Language Classroom: Issues and Implementation (pp. 53-67). Multilingual Matters Ltd. https://doi.org/10.21832/9781788923415-010

Creswell, J. W. (2014). Research Design: Qualitative, Quantitative, and Mixed Methods Approaches (4th ed.). Los Angeles, CA: Sage.

Crane, C. (2020). Transforming Our Perspectives as Language Professionals During COVID119. Second Language Research and Practice, 1(1), 168-173. 
Arab World English Journal (AWEJ) 2nd Special Issue on Covid 19 Challenges January 2022

Creswell, J. W., Plano Clark, V. L., Gutmann, M., Hanson, W. (2003). Advanced Mixed Methods Research Designs. In A. Tashakkori, \& C. Teddlie (Eds.), Handbook of Mixed Methods in Social and Behavioral Research (pp. 209-240). Thousand Oaks, CA: Sage.

Creswell, J. W., \& Plano Clark, V. L. (2006). Designing and Conducting Mixed Methods Research. Thousand Oaks, CA: Sage.

Creswell, J.W., \& Plano Clark V.L. (2011). Designing and Conducting Mixed Methods Research. Thousand Oaks, CA: Sage.

Chandasiri, O. (2020). The COVID-19: Impact on Education. Journal of Asian and African Social Science and Humanities, 6(2), 37-42.

Dorand, P. (2020). Analyzing Online Learning Satisfaction and Language Learning Strategies Use. Journal of Informatics and Communications Technology, 2(2), 39- 48.

Dutta, A. (2020). Impact of Digital Social Media on Indian Higher Education: Alternative Approaches of Online Learning during COVID-19 Pandemic Crisis. International Journal of Scientific and Research Publications (IJSRP), 10(05), 604-611. DOI: http://dx.doi.org/10.29322/IJSRP.10.05.2020, 10169.

Fabian, M. et al. (2020). Use of Social Networks as a Technology of Foreign Language Teaching. Journal of Critical Reviews (JCR), 7(14), 502-505. DOI: 10.31838/jcr.07.14.86

Ferdig, R. E., Baumgartner, E., Hartshorne, R., Kaplan-Rakowski, R., \& Mouza, C. (Eds.), (2020). Teaching, Technology, and Teacher Education during the COVID-19 Pandemic: Stories from the Field. Association for the Advancement of Computing in Education (AACE). Retrieved from https://www.learntechlib.org/primary/p/216903/.

Gillham, B., (2000). Developing a Questionnaire. London: Continuum.

Grasse, M.A. (2020). Empowering Language Learning Strategies Online. GATESOL in Action Journal, 30 (1), 70-79. DOI: https://doi.org/10.52242/giaj.v30i1.100

Greene, J. C. (2007). Mixed Methods in Social Inquiry. San Francisco, CA: John Wiley \& Sons.

Harasim, L. (2012). Learning Theory and Online Technologies. New York, NY: Routledge/Taylor \& Francis.

Hodges, C., Moore, S., Lockee, B., Trust, T., \& Bond, A. (2020). The Difference Between Emergency Remote Teaching and Online Learning. Edu-CAUSE Review. https://er.educause.edu/articles/2020/3/the-difference-between-emergency-remoteteaching-and-online-learning

Hrotková, S. (2010). In Search of New Ways of how to Make Foreign Language Lessons More Effective. Trnava: Perspektívy Výučby Cudzich Jazykov Pre 21. Storočie, 27-31.

Karchmer-Klein, R., \& Pytash, K. E. (Eds), 2020. Effective Practices in Online Teacher Preparation for Literacy Educators. IGI Global. DOI: 10.4018/978-1-7998-0206-8

Kosturková, M. (2011). Development of Critical Thinking by University Students. Prešov: MVEK.

Lacková, M., (2021). Learning Medicine Vocabulary through Corpus. Žilina: EDIS.

Mariononi, G., Land, H., \& Jensen, T. (2020). The Impact of COVID-19 on Higher Education Around the World. Paris: International Association of Universities. Retrieved from https://www.iauaiu.net/IMG/pdf/iau_covid19 and he survey_report_final_may_2020.pdf

Metruk, R. (2020). EFL Learners' Perspectives on the Use of Smartphones in Higher Education Settings in Slovakia. The Electronic Journal of e-Learning, 18(6), 537-549. DOI: 10.34190/JEL.18.6.006 
Morse, J. M. (1991). Approaches to Qualitative-Quantitative Methodological Triangulation. Nursing Research, 40, 120-123.

New Pedagogy is Emerging, and Online Learning is a Key Contributing Factor, (2020). Retrieved from: https://teachonline.ca/tools-trends/how-teach-online-studentsuccess/new-pedagogy-emerging-and-online-learning-key-contributing-factor

Odriozola-González, P., Planchuelo-Gómez, A., JesúsIrurtia, M., Luis-García, R. (2020). Psychological Effects of the COVID-19 Outbreak and Lockdown among Students and Workers of a Spanish University. Psychiatry Research, 113-108. DOI: 10.1016/j.psychres.2020.113108

Our Quality Framework. (2021). Retrieved from: https://onlinelearningconsortium.org/about/quality-framework-five-pillars/

Picciano, A. G. (2009). Blending with Purpose: The Multimodal Model. Journal of Asynchronous Learning Networks, 13(1), 7-18.

Sahu, P. (2020). Closure of Universities Due to Coronavirus Disease 2019 (COVID-19): Impact on Education and Mental Health of Students and Academic Staff. Cureus. T. 12, №. 4. DOI: $10.7759 /$ cureus.7541

Siemens, G. (2004). Connectivism: A Learning Theory for a Digital Age. Retrieved from https://jotamac.typepad.com/jotamacs_weblog/files/Connectivism.pdf

Soland, J. et al. (2020). The Impact of COVID-19 on Student Achievement and what it May Mean for Educators. Brookings. Retrieved from https://www.brookings.edu/blog/brown-centerchalkboard/2020/05/27/the-impact-of-covid-19-on-stu-dent-achievement-and-what-itmay-mean-for-educators/

Stukalo, N., \& Simakhova, A. (2020). COVID-19 Impact on Ukrainian Higher Education. Universal Journal of Educational Research, 8(8), 3673-3678, 2020. DOI: 10.13189/ujer.2020.080846

Stukalo, N., \& Dluhopolskyi, O. (2020). Educational Programs Accreditation in Pandemic Times: Challenges for NAQA (Ukraine). Revista Romaneasca pentru Educatie Multidimensionala, 12 (1Sup2), 167-172. DOI: https://doi.org/10.18662/rrem/12.1sup2/260

Tashakkori, A., \& Teddlie, C. (1998). Mixed Methodology: Combining Qualitative and Quantitative Approaches. Thousand Oaks, CA: Sage.

Viner, R. M. et al. (2020). School Closure and Management Practices During Coro-Navirus Outbreaks Including COVID-19: A Rapid Systematic Review. The Lancet Child \& Adolescent Health, 4(5), 397-404. DOI:10.1016/s2352-4642(20)30095-x

Ushida, E. (2005). The Role of Students' Attitudes and Motivation in Second Language Learning in Online Language Courses. CALICO Journal, 23(1), 49-78.

Williams, R. (2003). Integrated Distributed Learning with Just-In-Context Knowledge Management. Electronic Journal of e-learning, 1(1), 45-50.

Xiao, J., \& Hurd, S. (2007). Language Learning Strategies in Distance English Learning: A Study of Learners at Shantou Radio and Television University, China. The Journal of Asia TEFL, 4(2), 141-164. 